\title{
Sedimentation in the Three Gorges Dam and the future trend of Changjiang (Yangtze River) sediment flux to the sea
}

\author{
Bangqi Hu ${ }^{1,2}$, Zuosheng Yang ${ }^{1,2}$, Houjie Wang ${ }^{1,2}$, Xiaoxia Sun ${ }^{1,2}$, Naishuang $\mathbf{B i}^{2}$, and Guogang $\mathbf{~ L i}^{3}$ \\ ${ }^{1}$ College of Marine Geosciences, Ocean University of China, 238 Songling Rd., Qingdao 266100, China \\ ${ }^{2}$ Key Lab of Submarine Sciences \& Prospecting Techniques (KLSSET), Ministry of Education, 238 Songling Rd., \\ Qingdao 266100, China \\ ${ }^{3}$ North China Sea Branch of the State Oceanic Administration, 22 Fushun Rd., Qingdao 266033, China
}

Received: 17 July 2009 - Published in Hydrol. Earth Syst. Sci. Discuss.: 29 July 2009

Revised: 5 November 2009 - Accepted: 8 November 2009 - Published: 26 November 2009

\begin{abstract}
The Three Gorges Dam (TGD) on the upper Changjiang (Yangtze River), China, disrupts the continuity of Changiiang sediment delivery to downstream and coastal areas. In this study, which was based on 54 years of annual water and sediment data from the mainstream and major tributaries of Changjiang, sediment deposition induced by the TGD in 2003-2008 was quantified. Furthermore, we determined the theoretical trapping efficiency of the cascade reservoir upstream of the TGD. Its impact on Changjiang sediment flux in the coming decades is discussed. Results show that about 172 million tons (Mt) of sediment was trapped annually by the TGD in 2003-2008, with an averaged trapping efficiency of $75 \%$. Most of the total sediment deposition, as induced by the TGD (88\%), accumulated within the region between the TGD site and Cuntan. However, significant siltation (12\% of the total sediment deposition) also occurred upstream of Cuntan as a consequence of the upstream extended backwater region of the TGD. Additionally, the Changjiang sediment flux entered a third downward step in 2001, prior to operation of the TGD. This mainly resulted from sediment reduction in the Jinshajiang tributary since the late 1990s. As the cascade reservoir is put into full operation, it could potentially trap $91 \%$ of the Jinshajiang sediment discharge and, therefore, the Jinshajiang sediment discharge would most likely further decrease to $14 \mathrm{Mt} / \mathrm{yr}$ in the coming decades. Consequently, the Changjiang sediment flux to the sea is expected to continuously decrease to below $90 \mathrm{Mt} / \mathrm{yr}$ in the near future, or only $18 \%$ of the amount observed in the 1950s. In the presence of low sediment discharge, profound impacts on the morphology of estuary, delta and coastal waters are expected.
\end{abstract}

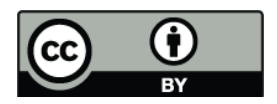

Correspondence to: Zuosheng Yang (zshyang@mail.ouc.edu.cn)

\section{Introduction}

Rivers are conveyor belts for terrestrial material delivery to the oceans (Walling and Fang, 2003; Walling, 2006), and they annually transport a $15-20 \mathrm{Gt}$ sediment load to the global oceans (Milliman and Meade, 1983; Milliman and Syvitski, 1992). These large amounts of sediment play an important role in the global geological cycle, the global geochemical cycle, the coastal ecosystems and the evolution of deltas. However, dam construction interrupts the continuity of a river system in transporting sediments to downstream and coastal regions (Kondolf, 1997). During the latter half of the 20th century, about 45000 large dams over $15 \mathrm{~m}$ high and an estimated 800000 small dams had been built worldwide, representing nearly an order of magnitude increase compared to the year 1950 (WCD, 2000). It is estimated that more than $30 \%$ of the global sediment flux is trapped in reservoirs (Vörösmarty et al., 2003), and approximately $0.5 \%$ to $1 \%$ of the world's total reservoir volume is lost each year as a result of sedimentation (WCD, 2000). Subsequently, the global sediment flux from the rivers to the sea has decreased significantly (Milliman, 1997; Syvitski et al., 2005).

The Changjiang (Yangtze River) of China is a worldclass river, it ranks fifth in terms of water discharge $\left(920 \mathrm{~km}^{3} / \mathrm{yr}\right)$ and historically is fourth in terms of sediment load (480 Mt/yr) (Milliman and Meade, 1983; Milliman and Syvitski, 1992). During the past five decades, the Changjiang water discharge has remained almost unchanged; however, the Changjiang sediment flux to the sea has experienced a distinct reduction. According to Yang et al. (2006b), the Changjiang displayed three phases of sediment reduction since the 1950s, including: following the Danjiangkou Reservoir on the Hanjiang in 1968 and after the construction of numerous dams and soil conservation projects in the Jialingjiang Basin in 1985. As the Three Gorges Dam (TGD)

Published by Copernicus Publications on behalf of the European Geosciences Union. 


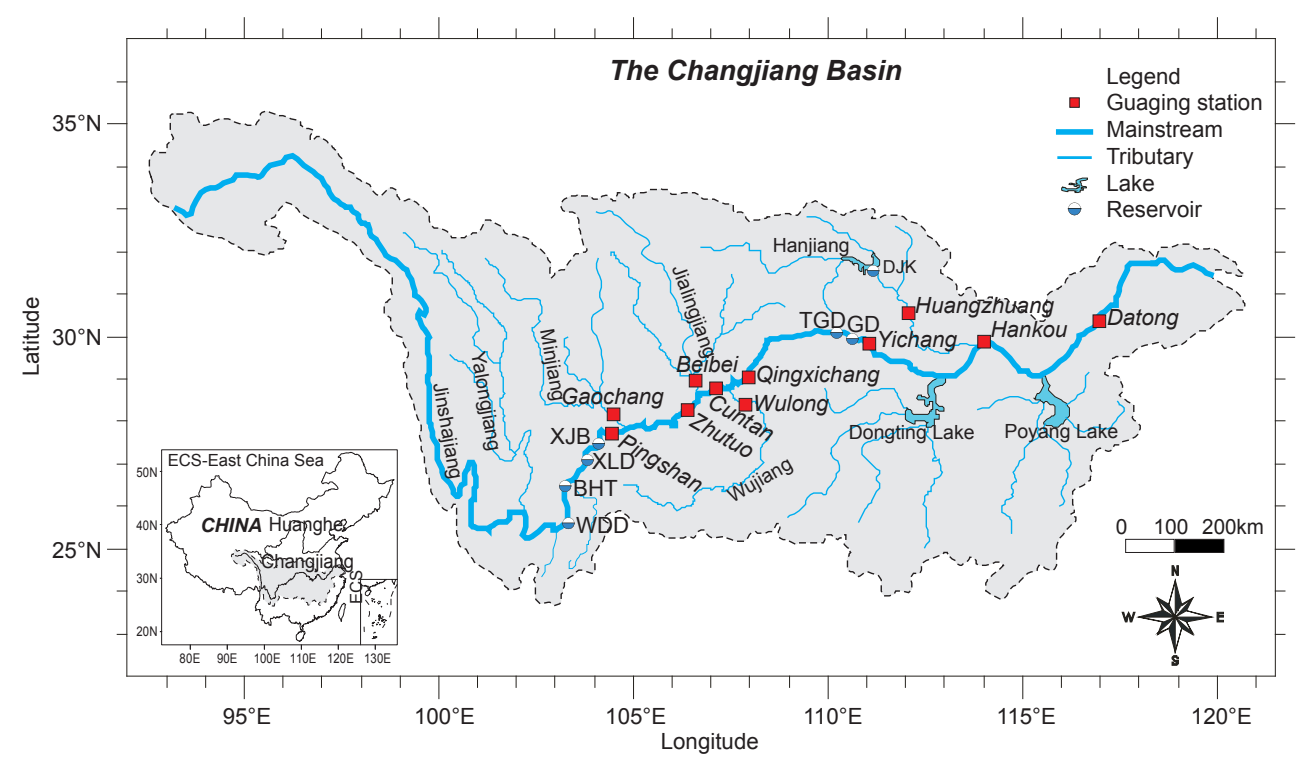

Fig. 1. The Changjiang drainage basin (DJK, Danjiangkou Reservoir; TGD, Three Gorges Dam; GD, Gezhouba Dam; XJB, Xiangjiaba Reservoir; XLD, Xiluodu Reservoir; BHT, Baihetan Reservoir; WDD, Wudongde Reservoir).

began operations in 2003, the Changjiang sediment flux entered a third downward step. This anti-phase relationship between the Changjiang water and sediment discharge illustrates the predominant impact of human activities on the sediment yield, transport and storage in this large river system (Yang et al., 2002, 2006b; Chen et al., 2005; Zhang et al., 2009). Of human activities, dam construction is the dominant factor (88\%) contributing to the reduction in Changjiang sediment flux to the sea (Dai et al., 2008). Here, we mainly focused on the TGD (Fig. 1), which is the largest dam in the world. It is located at the end of the upper Changjiang. The water storage capacity of the TGD will be $39 \mathrm{~km}^{3}$ by 2009 , which is approximately $4.3 \%$ of the long-term annual water discharge at Datong $\left(903 \mathrm{~km}^{3}\right.$ in 1950-2005).

After the TGD began to impound water and trap sediment in June 2003, the mainstream of the Changjiang has been disrupted in two parts, both upstream and downstream of the TGD (Dai et al., 2006; Yang et al., 2007a). Upstream of the TGD, the primary consequence is sedimentation. Sedimentation in reservoirs results in a progressive reduction in storage capacity and triggers a series of physical, chemical and ecological impacts on the environment. One key to assess its environment impacts is the quantitative study of reservoir sedimentation. Previous studies have estimated the annual sedimentation in the TGD by the sediment budget method; however, the reported values have been quite different from each other (Bulletin of Changjiang Sediment, 2003-2008; Dai et al., 2006; Yang et al., 2006b, 2007b; Chu and Zhai, 2008; Xu and Milliman, 2009). These differences are mainly caused by: (1) the different stations that were used as the upstream limit of the TGD (e.g., Qingxichang vs. Cuntan, see Fig. 1); (2) whether or not the influence of sediment from ungauged areas was considered; and (3) whether or not sediment erosion within the channel between the TGD site and Yichang was considered. Thus, to better understand the scientific and management issues of this giant reservoir, it is necessary to recalculate the sedimentation rate in the TGD by undertaking a thorough quantification study.

Although the Changiiang sediment flux had decreased by approximately $30 \%$ before the impoundment of the TGD in 2003 , the impact of the TGD on downstream sediment transport was more immediate and sharp (Yang et al., 2006b, 2007a; Hu et al., 2009; Xu and Milliman, 2009). The consequences of TGD trapping were downstream erosion, delta degradation and wetlands loss (e.g., Yang et al., 2003, 2005, 2006a, 2007a, 2007b; Chen et al., 2008; Xu and Milliman, 2009). It also posed a great threat to the downstream and coastal ecosystems (Xie et al., 2003; Shen and Xie, 2004). Therefore, changes in the Changjiang sediment flux caused by the impoundment of TGD after 2003 have garnered increasing attention and concern.

Several studies (Yang et al., 2002, 2003, 2005, 2006b) have estimated the Changjiang sediment flux (recorded at Datong), after the TGD implementation, based on the estimated sediment load out of TGD (Yichang) and the correlation between sediment data at Yichang and Datong before TGD. However, Chen et al. (2008) have argued that these above estimates appear to overestimate the sediment discharge entering the TGD in the post-TGD period. Xu et al. (2007) also indicated that the correlation between sediment load at Yichang and Datong, after TGD, has been fundamentally changed. More recently, by considering the impact of the cascade reservoir that is located on the upstream side of the TGD (Fig. 1), Yang et al. (2006a, 2007a, b) 
Table 1. Detailed hydrological records of stations at the mainstream and major tributaries of the Changjiang. Data series are 1950 s-2005.

\begin{tabular}{llllcc}
\hline \multicolumn{2}{c}{ Rivers } & Stations & $\begin{array}{l}\text { Area } \\
\left(10^{4} \mathrm{~km}^{2}\right)\end{array}$ & $\begin{array}{c}\text { Water discharge } \\
\left(\mathrm{km}^{3} / \mathrm{yr}\right)\end{array}$ & $\begin{array}{c}\text { Sediment load } \\
(\mathrm{Mt} / \mathrm{yr})\end{array}$ \\
\hline \multirow{6}{*}{ Tributary } & Jinshajiang & Pingshan & 45.86 & 145 & 249 \\
& Jialingjiang & Beibei & 15.61 & 66 & 111 \\
& Minjiang & Gaochang & 13.54 & 50 & 26 \\
& Wujiang & Wulong & 8.30 & 86 & 48 \\
& Hanjiang & Huangzhuang & 14.21 & 47 & 52 \\
\hline \multirow{6}{*}{ Changjiang } & & Zhutuo & 69.47 & 269 & 302 \\
\cline { 3 - 6 } Mainstream & \multirow{2}{*}{ Upper } & Cuntan & 86.66 & 348 & 418 \\
& & Yichang & 100.55 & 436 & 470 \\
\cline { 3 - 6 } & \multirow{2}{*}{ Mid-Lower } & Hankou & 148.80 & 712 & 384 \\
& & Datong & 170.54 & 903 & 414 \\
\hline
\end{tabular}

suggest that the Changjiang sediment flux will decrease to about $100-150 \mathrm{Mt} / \mathrm{yr}$ in the next six decades. Similarly, Chen et al. (2008) indicate that the Changjiang sediment flux over the post-TGD period will possibly vary from $112 \mathrm{Mt} / \mathrm{yr}$ to $132 \mathrm{Mt} / \mathrm{yr}$ or less in ordinary years. Nevertheless, these results (Yang et al., 2006a, 2007a, b; Chen et al., 2008) are still under debate, due to the impact of the cascade reservoir, which was only partly or qualitatively discussed.

In this paper, we will discuss the effect of the TGD on the Changiiang hydrographic regime, through its two parts that are separated by the TGD site. The upper part is the mainstream from Pingshan to Yichang and the lower part is from Yichang to Datong (Fig. 1). Hydrological data were temporally separated into two periods according to the TGD operation in 2003, including: the pre-TGD period and the postTGD period. The main objectives of this paper are: (1) to estimate the sedimentation rate in the TGD through analysis of the sediment data, both upstream and downstream of the TGD; (2) to give a quantified evaluation of the cascade reservoir's effect by estimating its theoretical trapping efficiency; and (3) to discuss the future trend of the Changjiang sediment flux into the sea in the coming decades.

\section{Physical setting}

The Changjiang originates from the Qinghai-Tibetan Plateau at an elevation of $5400 \mathrm{~m}$ and extends eastward $6300 \mathrm{~km}$ before debouching into the East China Sea (ECS) (Fig. 1). The Changjiang basin covers a drainage area of $1.81 \times 10^{6} \mathrm{~km}^{2}$, accounting for about $19 \%$ of China's national area (Chen et al., 2001). This large watershed is home to a population of more than 400 million, or $6.6 \%$ of the world's population (UNDES, 2001). The climate of the Changjiang basin is typically subtropical, wet and warm in summer, and moist and cool in winter. The annual mean temperature increases from below $4^{\circ} \mathrm{C}$ in the source area to approximately $5-15^{\circ} \mathrm{C}$ in the mountainous areas and approximately $16-18^{\circ} \mathrm{C}$ in the middle and lower reaches (Chen et al., 2002). The average precipitation and evaporation in the Changjiang basin are 1000$1400 \mathrm{~mm} / \mathrm{yr}$ and $700-800 \mathrm{~mm} / \mathrm{yr}$, respectively (Shen, 1986).

The upper Changjiang, with a drainage area of about $1.00 \times 10^{6} \mathrm{~km}^{2}$, extends $4500 \mathrm{~km}$ from the source to Yichang station. It is characterized by mountains and hills, with an average gradient of $1.1 \%$ (Yang et al., 2007a). Four major tributaries (Jinshajiang, Jialingjiang, Minjiang, and Wujiang) join the mainstream of the upper Changjiang (Fig. 1 and Table 1). The mid-lower Changjiang flows $1880 \mathrm{~km}$ from Yichang to Datong, with a drainage area of $0.8 \times 10^{6} \mathrm{~km}^{2}$. It flows through extensive fluvial plains, with several lakes (e.g., Dongting and Poyang Lakes, see Fig. 1) linked with the mainstream. Both of the two large lakes trap most of the sediment from their own drainage basins and greatly regulate the Changjiang sediment flux to the sea (Dai et al., 2005; Yang et al., 2007a; Chen et al., 2008). The Hanjiang is the largest tributary in the mid-lower Changjiang. Downstream of Datong, the river is tidally influenced. Therefore, the Datong water and sediment records are generally used to represent the mass flux of the Changiiang that is discharged into the sea, though it is over $600 \mathrm{~km}$ upstream from the river mouth. Within the Changjiang basin, the water and sediment distribution pattern is quite uneven. Most of the Changjiang sediment discharge to the sea mainly originates from the upper reaches, whereas water discharge from the upper reaches accounts for only $50 \%$, compared to that of Datong (Chen et al., 2001; Wang et al., 2008).

The TGD, at $181 \mathrm{~m}$ in height, $2335 \mathrm{~m}$ in length, and with a storage capacity of $39.3 \mathrm{~km}^{3}$ (Zhao et al., 2000), is the largest dam in the world (Nilsson et al., 2005). The TGD is a multifunctional hydroelectric facility used for flood control, hydropower generation and navigation. The dam began storing water and trapping sediment in June 2003. In addition, four large hydropower dams (Wudongde, Baihetan, Xiluodu and 
Table 2. The cascade reservoir on the lower Jinshajiang of the upper Changjiang (see Fig. 1 for locations, adapted from Liu, 2007).

\begin{tabular}{llllllll}
\hline Dam site & $\begin{array}{l}\text { Elevation } \\
(\mathrm{m})\end{array}$ & $\begin{array}{l}\text { Watershed } \\
\text { area } \\
\left(10^{4} \mathrm{~km}^{2}\right)\end{array}$ & $\begin{array}{l}\text { Average } \\
\text { inflow } \\
\left(\mathrm{km}^{3} / \mathrm{yr}\right)\end{array}$ & $\begin{array}{l}\text { Total } \\
\text { storage } \\
\left(\mathrm{km}^{3}\right)\end{array}$ & $\begin{array}{l}\text { Active } \\
\text { storage } \\
\left(\mathrm{km}^{3}\right)\end{array}$ & $\begin{array}{l}\text { Install } \\
\text { capacity } \\
(\mathrm{MW})\end{array}$ & $\begin{array}{l}\text { Annual } \\
\text { energy } \\
(\mathrm{GWh})\end{array}$ \\
\hline Wudongde & 723 & 39.6 & 120 & 5.86 & 2.62 & 8700 & 39.5 \\
Baihetan & 550 & 41.7 & 130 & 19.01 & 10.44 & 1305 & 57.7 \\
Xiluodu & 370 & 44.0 & 139 & 11.57 & 6.46 & 1260 & 57.4 \\
Xiangjiaba & 220 & 44.5 & 141 & 4.98 & 0.9 & 600 & 30.8 \\
\hline
\end{tabular}

Xiangjiaba) have been planned, taking advantage of a $730 \mathrm{~m}$ drop over $770 \mathrm{~km}$ of the river in the lower Jinshajiang (Fig. 1 and Table 2). The Xiluodu and Xiangjiaba Dams are now under construction and will be put into operation in 2013 and 2012, respectively. The other two dams, Wudongde and Baihetan, will start construction in 2010 and be put into operation in the 2020s (Liu, 2007; Yang et al., 2007b). The total storage capacity of the cascade reservoir on the lower Jinshajiang would be around $41.4 \mathrm{~km}^{3}$, which is about one third of the current annual water discharge of $145 \mathrm{~km}^{3}$ from the Jinshajiang tributary.

\section{Data collection and methods}

\subsection{Data collection}

Water and sediment data used in this study were mainly provided by the Changiiang Water Resources Commission (CWRC) and partly from the Bulletin of Changjiang Sediment (2000-2008), published by the CWRC (available in http://www.cjh.com.cn/). Bed load is not included in the present study, as its contribution to total load is less than $2 \%$ in the Changjiang (Yang et al., 2002, 2003). The locations and detailed hydrological records of stations are presented in Fig. 1 and Table 1.

\subsection{Estimates of sediment deposition caused by the TGD}

Yichang station is located $44 \mathrm{~km}$ downstream from the TGD site and, thus, it can act as the TGD output station. The water and sediment discharges of Yichang are mainly fed by Jinshajiang, Jialingjiang, Minjiang and Wujiang (Fig. 1). These four major tributaries collectively contribute $80 \%$ of the water discharge and $93 \%$ of the sediment load at Yichang station (Table 1). Fu et al. (2006) established a correlation between sediment load at Yichang and that from the four major tributaries in the pre-TGD period (1950s-2002). This correlation was also used by Chen et al. (2008) to calculate the total sediment entering the TGD during the post-TGD period. However, the sediment load at Yichang has displayed a distinct decreasing trend since the mid-1980s, as a result of intensi- fying human activity (e.g., dams and soil conservation) in the upper Changjiang basin (Fig. 2a) (Xu et al., 2006; Yang et al., 2006b; Xiong et al., 2009). Therefore, the sediment data for the period of 1986-2002 may be more representative of the condition just before the TGD than the whole period (1950s2002).

In this study, the time series of the sediment data were divided into two periods: the pre-TGD period (1986-2002) and the post-TGD period (2003-2008). Accordingly, two methods were used to estimate the sedimentation rate in the TGD. (1) First, we established the correlation between sediment load at Yichang and that from the four major tributaries during the pre-TGD period (1986-2002) (Fig. 2b). This correlation was used to restore the scenario of sediment load at Yichang in the post-TGD period. Differences between the restored and measured sediment load at Yichang in 20032008 were assumed to be equal to the reservoir sedimentation. (2) The other method was based on a sediment budget, which has been used in previous studies (e.g., Dai et al., 2006; Yang et al., 2007b, Chu and Zhai, 2008).

\subsection{Computing the theoretical trapping efficiency $(T E)$ of reservoirs}

The theoretical trapping efficiency (TE) of the large reservoirs $\left(>0.5 \mathrm{~km}^{3}\right)$ can be approximated using the empirical relationship originally developed by Brune (1953):

$T E=1-\frac{0.05}{\sqrt{\Delta \tau_{R}}}$

where $\Delta \tau_{R}$ is the local residence time change calculated with Eq. (2):

$\Delta \tau_{R}=\frac{\sum_{i}^{n} V_{i}}{Q}$

where $V_{i}$ is the storage capacity of the $i$-th reservoir $\left(\mathrm{km}^{3}\right)$ and $Q$ is the annual water discharge $\left(\mathrm{km}^{3} / \mathrm{yr}\right)$ at the dam site.

The theoretical $T E$ of the cascade reservoirs was calculated separately for each individual dam, using the results of annual water discharge at each dam site and the storage volume of the individual dam. With regard to the total cascade 
Table 3. Sediment budgets of the mainstream from Pingshan to Yichang (Unit: Mt/yr).

\begin{tabular}{|c|c|c|c|c|c|c|c|c|c|c|c|c|}
\hline \multirow[b]{2}{*}{ Periods } & \multirow[b]{2}{*}{$\begin{array}{l}\text { Jinshajiang } \\
\text { (Pingshan) }\end{array}$} & \multirow[b]{2}{*}{$\begin{array}{c}\text { Minjiang } \\
\text { (Gaochang) }\end{array}$} & \multirow[b]{2}{*}{$\begin{array}{c}\text { Jialingjiang } \\
\text { (Beibei) }\end{array}$} & \multirow[b]{2}{*}{$\begin{array}{l}\text { Wujiang } \\
\text { (Wulong) }\end{array}$} & \multirow[b]{2}{*}{ Cuntan } & \multirow[b]{2}{*}{ Yichang } & \multicolumn{3}{|c|}{ Sediment from the ungauged area } & \multicolumn{3}{|c|}{ Sediment deposition(+)/erosion(-) } \\
\hline & & & & & & & $\begin{array}{l}\text { Cuntan- } \\
\text { Pingshan }\end{array}$ & $\begin{array}{l}\text { Yichang- } \\
\text { Cuntan }\end{array}$ & $\begin{array}{l}\text { Yichang- } \\
\text { Pingshan }\end{array}$ & $\begin{array}{l}\text { Cuntan- } \\
\text { Pingshan }\end{array}$ & $\begin{array}{l}\text { Yichang- } \\
\text { Cuntan }\end{array}$ & $\begin{array}{l}\text { Yichang- } \\
\text { Pingshan }\end{array}$ \\
\hline 2003 & 156 & 48 & 31 & 14 & 206 & 98 & 32 & 11 & 43 & 61 & 133 & 194 \\
\hline 2004 & 148 & 34 & 18 & 11 & 173 & 64 & 22 & 7 & 29 & 49 & 127 & 176 \\
\hline 2005 & 188 & 59 & 42 & 4 & 270 & 110 & 37 & 11 & 48 & 56 & 175 & 231 \\
\hline 2006 & 90 & 21 & 3 & 3 & 109 & 9 & 10 & 2 & 12 & 15 & 105 & 120 \\
\hline 2007 & 150 & 31 & 27 & 10 & 210 & 53 & 25 & 9 & 34 & 23 & 176 & 199 \\
\hline 2008 & 204 & 15 & 14 & 4 & 212 & 32 & 32 & 5 & 37 & 53 & 189 & 242 \\
\hline $2003-2008$ & 156 & 35 & 23 & 8 & 197 & 61 & 26 & 8 & 34 & 43 & 151 & 194 \\
\hline 1956-2002 & 254 & 48 & 115 & 28 & 430 & 492 & 41 & 33 & 74 & 28 & -1 & 27 \\
\hline \multicolumn{10}{|c|}{ Sediment deposition caused by TGD } & 15 & 152 & 167 \\
\hline
\end{tabular}

Cuntan and Yichang are two mainstream stations for the upper Changjiang, and Jinshajiang, Minjiang, Jialingjiang and Wujiang are four major tributaries delivering sediment discharges into the mainstream (Fig. 1). The data of sediment from the ungauged areas are after Dai et al. (2006) and Yang et al. (2007a, b) or calculated by the same method. Sediment deposition(+)/erosion(-) from Yichang to Pingshan was calculated by subtracting Yichang from the sum of Jinshajiang, Minjiang, Jialingiiang, Wujiang and the ungauged area in Yichang-Pingshan. The budgets for Yichang-Cuntan and Cuntan-Pingshan were calculated in a similar way. The differences of sediment deposition between 1956-2002 and 2003-2008 were assumed to the TGD-induced.

reservoir, the volumes of each dam were summarized, and the annual water discharge used was the long-term mean water discharge at the aftermost station (Pingshan station).

Brune's method for calculating the theoretical $T E$, originally developed for reservoirs in the United States, is widely used for reservoirs in other parts of the world as well. This method can provide reasonable estimation of long-term and mean $T E$ of large reservoirs (e.g., Vörösmarty et al., 1997, 2003; Morris and Fan, 1998; Kummu and Varis, 2007).

\section{Results}

\subsection{Sediment deposition caused by the TGD}

On the basis of the annual sediment data at Yichang $\left(Q_{S} Y\right)$ and that from the four major tributaries $\left(Q_{S} T\right)$ of the upper Changjiang, linear regression equations in the pre-TGD (1986-2002) and post-TGD (2003-2008) periods were obtained as follows (Fig. 2):

Pre-TGD: $Q_{S} Y=1.125 Q_{S} T-20$

Post-TGD: $Q_{S} Y=0.554 Q_{S} T-61$

The coefficients of determination, $R^{2}$, for the above correlations were 0.85 and 0.71 , respectively, at a significance level of $P<0.01$. Mean annual sediment load at Yichang was estimated at 228 Mt for 2003-2008 by Eq. (3) (in the case of non-TGD). These estimated values can be viewed as the total sediment load entering the TGD (Chen et al., 2008) (Fig. 3). Thus, the differences between the estimated (nonTGD) and measured (with TGD operation) sediment load at Yichang were assumed equivalent to sediment deposition caused by the TGD. The mean annual sediment trapped by the TGD was $168 \mathrm{Mt} / \mathrm{yr}$ in 2003-2008, with the maximum sediment deposition (215 Mt) occurring in 2008 and the minimum (103 Mt) occurring in 2006 (Fig. 3).

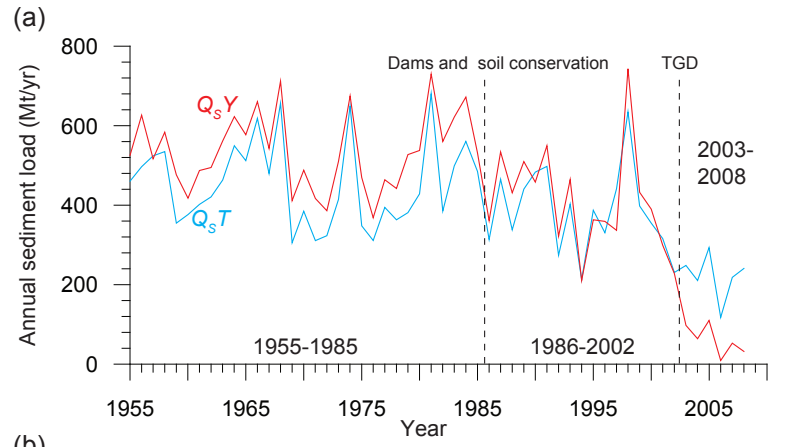

(b)

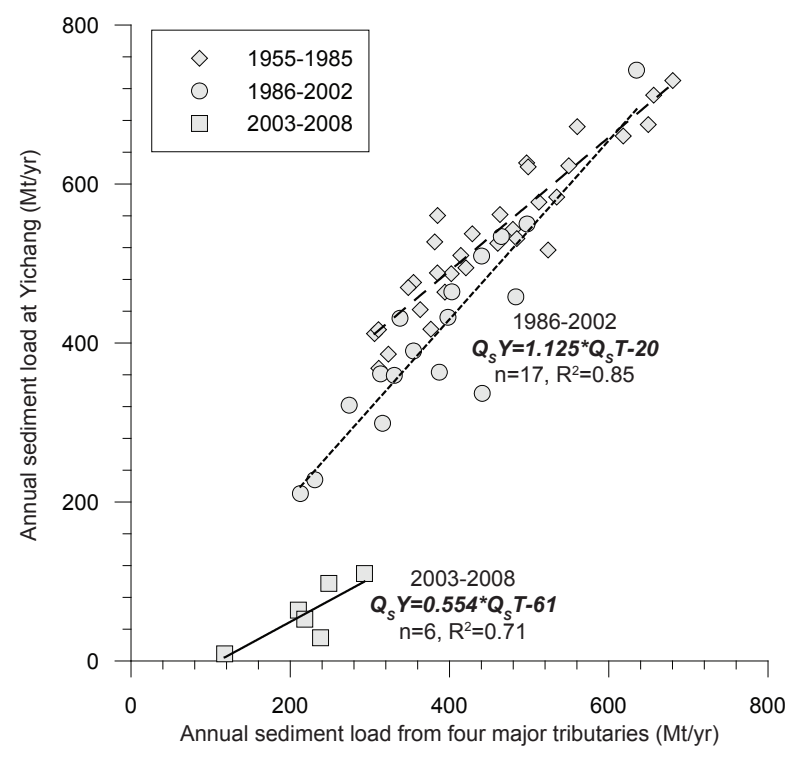

Fig. 2. Time series of annual sediment load at Yichang $\left(Q_{S} Y\right)$ and that from the four major tributaries $\left(Q_{S} T\right)$ from 1955-2008; (b) The correlations between $Q_{S} Y$ and $Q_{S} T$ in the pre-TGD (19862002) and post-TGD (2003-2008) periods. 


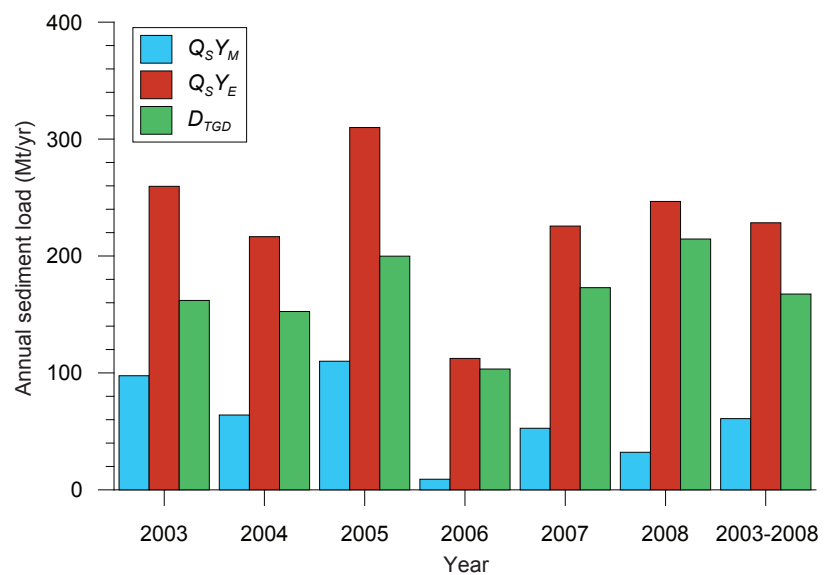

Fig. 3. Annual sediment load at Yichang and the sediment deposition caused by TGD in 2003-2008. The sediment deposition caused by TGD ( $D_{\mathrm{TGD}}$ ) was assumed to be the differences between the measured ( $Q_{S} Y_{M}$, with the TGD operation) and the estimated $\left(Q_{S} Y_{E}\right.$, non-TGD) sediment load at Yichang.

To validate the above estimated results, we also established the sediment budgets of the mainstream reaches from Yichang to Pingshan, which was subdivided into two sections: (1) the lower section from Yichang to Cuntan and (2) the upper section from Cuntan to Pingshan. Results of the sediment budgets show that sediment deposition from Yichang to Pingshan has increased from $27 \mathrm{Mt} / \mathrm{yr}$ in 19562002 to $194 \mathrm{Mt} / \mathrm{yr}$ in 2003-2008, indicating that the TGDinduced sediment deposition averaged $167 \mathrm{Mt} / \mathrm{yr}$ in 2003 2008 (Table 3). This is very close to the above estimated result of $168 \mathrm{Mt} / \mathrm{yr}$, by our formula (Fig. 3). The sediment budgets also provided insight into the distribution pattern of the sediment deposition caused by the TGD. The data suggest that $152 \mathrm{Mt} / \mathrm{yr}$ of the sediment deposition caused by TGD was deposited in the lower section from Yichang to Cuntan, and the remaining $15 \mathrm{Mt} / \mathrm{yr}$ was deposited in the upper section from Cuntan to Pingshan (Table 3).

As the mainstream channel between the TGD site and Yichang suffered from serious erosion after the TGD operation (Bulletin of Changjiang sediment, 2003; Yang et al., 2007a, b), the sediment trapping effect of the TGD would be underestimated by both methods, as discussed above. In 2003-2008, sediment load increased from $58 \mathrm{Mt} / \mathrm{yr}$ at Huanglingmiao (just $13 \mathrm{~km}$ downstream of the TGD) to $61 \mathrm{Mt} / \mathrm{yr}$ at Yichang (44 km downstream of the TGD) (Bulletin of Changjiang sediment, 2003-2008). Because there are no small tributaries joining the mainstream between the TGD site and Yichang, this increase of $3 \mathrm{Mt} / \mathrm{yr}$ in sediment can be attributed to the riverbed erosion between the two stations, with a sediment erosion rate of $0.1 \mathrm{Mt} / \mathrm{km} / \mathrm{yr}$. Given this sediment erosion rate for the whole channel, from the TGD site to Yichang ( $44 \mathrm{~km}$ channel length), the total sediment erosion between the TGD site and Yichang was calculated as
Table 4. The theoretical trapping efficiency for the cascade reservoir on the lower Jinshajiang and the TGD with different water levels.

\begin{tabular}{lcccc}
\hline Dam & $Q^{\mathrm{a}}\left(\mathrm{km}^{3} / \mathrm{yr}\right)$ & $V^{\mathrm{b}}\left(\mathrm{km}^{3}\right)$ & $\Delta \tau_{R}^{\mathrm{c}}$ & $T E^{\mathrm{d}}$ \\
\hline Wudongde & 120 & 5.9 & 0.05 & $77 \%$ \\
Baihetan & 130 & 19.0 & 0.15 & $87 \%$ \\
Xiluodu & 139 & 11.6 & 0.08 & $83 \%$ \\
Xiangjiaba & 141 & 5.0 & 0.04 & $73 \%$ \\
Cascade & 145 & 41.4 & 0.29 & $91 \%$ \\
& 436 & $13.6(139 \mathrm{~m})$ & 0.03 & $72 \%$ \\
TGD & 436 & $23.1(156 \mathrm{~m})$ & 0.05 & $78 \%$ \\
& 436 & $39.3(175 \mathrm{~m})$ & 0.09 & $83 \%$ \\
\hline
\end{tabular}

a Annual water Discharge at the dam locations (Liu, 2007).

b Storage volume (Liu, 2007; Yang et al., 2005).

${ }^{\mathrm{c}}$ Local residence time, Eq. (2).

d TE calculated using the Brune's method, Eq. (1).

4.4 Mt/yr in 2003-2008. This amount of sediment should be added to the sediment deposition in the lower section, from the TGD site to Cuntan. In conclusion, the total sediment trapped by the TGD averaged $172 \mathrm{Mt} / \mathrm{yr}$ in 2003-2008, of which $88 \%$ was trapped in the lower section, from the TGD site to Cuntan, and the remaining $12 \%$ was deposited upstream of Cuntan. In 2003-2008, the estimated sediment $T E$ of the TGD averaged $75 \%$.

\subsection{Theoretical trapping efficiency of the reservoirs}

Four large dams, Wudongde, Baihetan, Xiluodu and Xiangji$\mathrm{aba}$, with a total storage capacity $\left(41.4 \mathrm{~km}^{3}\right)$ greater than the TGD, are now under construction or will be constructed upstream of the TGD (Fig. 1 and Table 2). To evaluate the impact of the whole cascade reservoir on the Changjiang sediment flux in the coming decades, the theoretical $T E$ was calculated using Brune's method. The theoretical $T E$ for the individual dams of the cascade reservoir varies from $73 \%$ to $87 \%$. On completion of the cascade reservoir, it would be theoretically capable of trapping $91 \%$ of the sediment discharge coming from the Jinshajiang basin (Table 4). The theoretical TE of the TGD was $73 \%$ and $78 \%$, with a water elevation of $139 \mathrm{~m}$ and $156 \mathrm{~m}$, respectively (Table 4). This approximates the real TE of 75\% in 2003-2008, when the water elevation varied from $139 \mathrm{~m}$ to $156 \mathrm{~m}$. As the water elevation of TGD rises to $175 \mathrm{~m}$ after 2009, the theoretical $T E$ of the TGD will be up to $83 \%$, which is much more than the value of $69 \%$ estimated by Yang et al. (2005).

The theoretical $T E$ values for the Xiluodu and Xiangjiaba Reservoirs, calculated herein, are similar to the results of previous studies (Huang and Huang, 2002; Hu et al., 2003; Tang and He, 2003). These results suggest that Brune's method can be used to estimate the $T E$ of reservoirs in the upper Changjiang basin. Otherwise, it should be noted that actual 
Table 5. Summary of the estimated sedimentation rate in the TGD (Unit: Mt/yr).

\begin{tabular}{ccl}
\hline Sedimentation rate (Mt/yr) & Time scale & Reference \\
\hline 110 & $2003-2004$ & Yang et al., 2006b \\
118 & $2003-2006$ & Xu and Milliman, 2009 \\
122 & $2003-2004$ & Dai et al., 2006 \\
125 & 2003 & Chu and Zhai, 2008 \\
138 & $2003-2008$ & CWRC, 2003-2008 \\
151 & $2003-2005$ & Yang et al., 2007b \\
172 & $2003-2008$ & This study \\
\hline
\end{tabular}

sediment trapping in the reservoir was constrained by not only the local residence time related to its storage capacity, but also the sediment supply from the upstream basin. For example, although the Baihetan Reservoir has the highest theoretical $T E$ of $87 \%$ in the Jinshajiang cascade reservoirs, it probably would not trap much sediment as a result of the upstream Wudongde Reservoir's sediment buffering effect.

By contributing around $60 \%$ of the total sediment discharge from the upper reaches into the TGD, the Jinshajiang became the major sediment source of the Changjiang, both pre- and post-TGD. After the cascade reservoir on the lower Jinshajiang is put into full operation in the 2020s, the sediment passing Pingshan will most likely decrease sharply to ca. $14 \mathrm{Mt} / \mathrm{yr}$ (9\% of $156 \mathrm{Mt} / \mathrm{yr}$ in 2003-2008). If the sediment discharge from other sub-basins maintains present levels (99 Mt/yr in 2003-2008) (Table 3), the total sediment discharge entering the TGD will decrease to $113 \mathrm{Mt} / \mathrm{yr}$ in the next decade, which is less than half of that in 2003-2008. Given that the $T E$ of the TGD, with its water elevation at $175 \mathrm{~m}$ after 2009 , is $83 \%$ (Table 4), the sediment discharge passing Yichang would be only around $19 \mathrm{Mt} / \mathrm{yr}$ in the coming decades.

\section{Discussion}

\subsection{The upstream extending backwater region of the TGD in 2003-2008}

By considering the influences of the sediment source from the ungauged area and the riverbed erosion within the channel between the TGD site and Yichang, Yang et al. (2007b) reported the highest sedimentation rate of $151 \mathrm{Mt} / \mathrm{yr}$ in the TGD (Table 5). However, the significant siltation in the upstream area of Cuntan (15 Mt/yr in 2003-2008) was underestimated or neglected in previous studies. This siltation may be related to the upstream extended backwater region of the TGD. When sediment deposited in the backwater region, as a result of the decreased current velocity and sediment carrying capacity, it brings a feedback mechanism. This allows the depositional environment to propagate much farther upstream than the initial hydraulic backwater curve might sug-

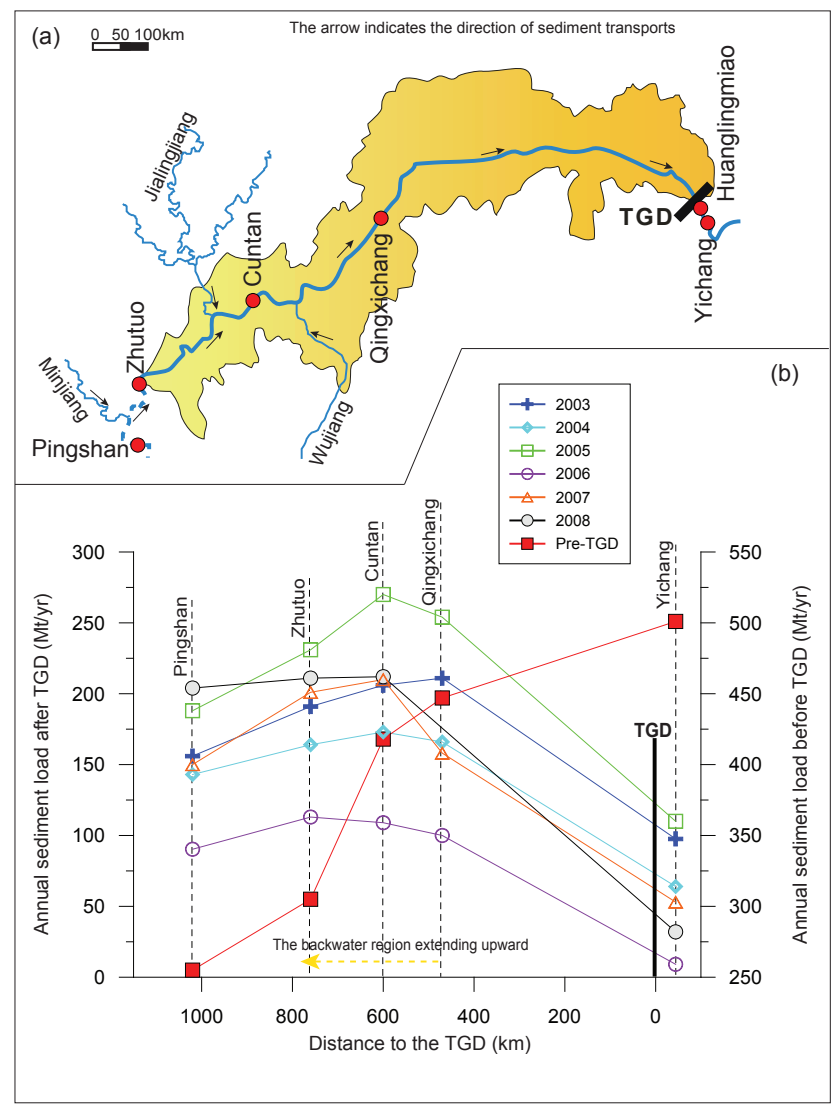

Fig. 4. (a) The sketch map of the Three Gorges Dam (TGD); (b) The annual sediment load after the impoundment of the TGD in comparison with the long-term average values (Pre-TGD, 1950s2000) at the stations along the upper Changjiang. It is suggested that the backwater region of TGD has upstream extended beyond Zhutuo station in 2006 (760 km upstream of the TGD site). Note that the sediment load at Qingxichang in 2008 is not available.

gest (Goodwin et al., 2000). This extended backwater region was observed in numerous dam systems, including the Aswan High Dam on the Nile River in Egypt (El-Manadely et al., 2002), the Sardar Sarovar Dam on the Narmada River in Indus (Bettess, 1993), and the Sanmenxia reservoir on the Yellow River in China (Wang et al., 2007b). This phenomenon of the upstream extended backwater region appears to occur in the TGD as well.

According to the TGD design scheme, the upstream limit of the backwater region was Qingxichang when its water elevation was $139 \mathrm{~m}$ in 2003-2005, Cuntan for $156 \mathrm{~m}$ in 20062008 and Zhutuo for $175 \mathrm{~m}$ after 2009 (Fig. 4a). However, Wang et al. (2007a) indicated that the backwater region of the TGD extended upstream farther than the Qingxichang in 2003. Dai et al. (2006) also noticed a significant siltation in the upstream of Qingxichang in 2003 and 2004. Furthermore, the variation of sediment load at the stations along the upper Changjiang demonstrated the impact of the extended TGD backwater region on sediment transport in the upper 
Changjiang in 2003-2008. As shown in Fig. 4b, sediment load along the upper Changjiang increased from $254 \mathrm{Mt} / \mathrm{yr}$ at Pingshan to $492 \mathrm{Mt} / \mathrm{yr}$ at Yichang during the pre-TGD period, indicating an additional sediment input of the tributaries and/or riverbed erosion. After the TGD was put into operation, however, the sediment load began decreasing from Qingxichang in 2003, from Cuntan in 2004 and 2005, and from Zhutuo after 2006. This indicates that the backwater region of the TGD has extended gradually upstream from Qingxichang (470 km upstream of the TGD) to Zhutuo (760 km upstream of the TGD), accompanied by sediment deposition in these regions. As the water elevation of the TGD increases to $175 \mathrm{~m}$ after 2009, the backwater region of the TGD may be extended further upstream. Consequently, the trapping of more sediment within the extended backwater region is expected. The impact of this on local environments should attract more attention.

Due to the short-term data of the post-TGD period, as well as the rough sediment budgets, a rigorous upstream limit of the TGD backwater region cannot be obtained at present. Otherwise, the sedimentation rate of the TGD calculated herein reflects only the suspended sediment load. Undoubtedly all of the bed loads coming from the upper reaches of the TGD are trapped as well, though the amounts of bed loads are unclear. These bed loads are most likely deposited in the backwater region of the TGD, owing to the reduced current velocity and sediment carrying capacity in this region. In addition, landslides and debris flows, taking place around the margins of the new TGD-induced high lake, will also contribute large amounts of sediment into the TGD, especially when the TGD water level fluctuates during floods and drawdowns. Both of these would increase the sedimentation rate of the TGD. Therefore, more in-situ investigations are required for future studies. These investigations should include repeat bathymetric surveys and/or coring at key locations, as suggested by Snyder et al. (2004), which may provide more detail about depositional processes and the history of the TGD.

\subsection{Prior reduction of the Changjiang sediment flux before the TGD}

As the Changjiang sediment flux is mainly supplied by the upper reaches (Chen et al., 2001), the correlation of sediment load between Yichang and Datong was well established during the pre-TGD period (Fig. 5). As indicated by Yang et al. (2006b), the correlation between Yichang and Datong gradually became significant (Fig. 5b). For the period of 1953-1968, before the impoundment of the Danjiangkou Reservoir, the Hanjiang was the largest sediment contributor to the mainstream of Changjiang below Yichang. Additionally, the Dongting Lake plays an important role in regulating the Changjiang sediment flux (Dai et al., 2005; Yang et al., 2007a). In 1953-1968, a large amount (35\%) of sediment coming from Yichang was deposited in the Dongting
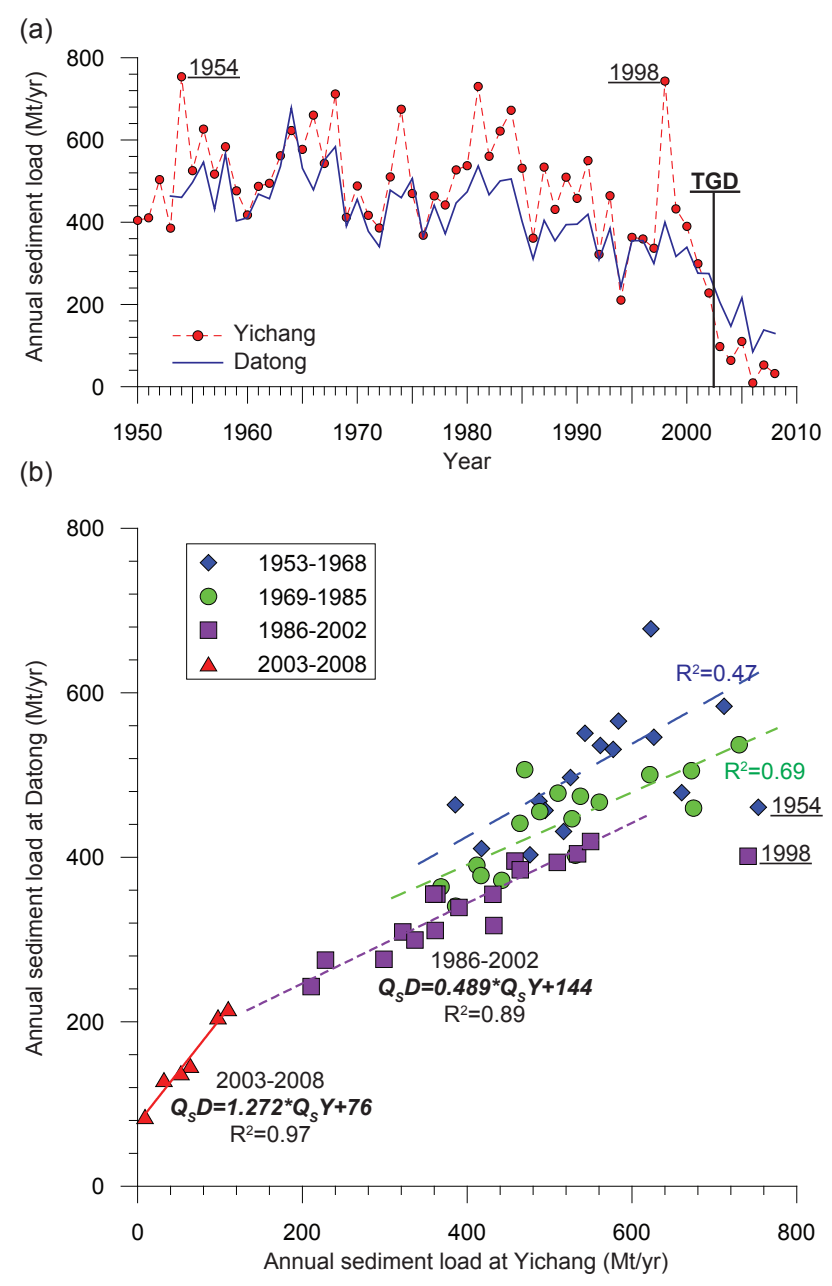

Fig. 5. (a) Comparison with the sediment load at Yichang and Datong from 1950-2008. In the extreme floods years of 1954 and 1998 , about $100 \mathrm{Mt}$ of sediments were lost in the middle reaches through the river breaches and overbank flows (Yang et al., 2006b); (b) Correlations between sediment load at Yichang and Datong during the different periods (modified from Yang et al., 2006b, the extreme flood years of 1954, 1998 were excluded).

Lake (Dai et al., 2005; Xu et al., 2007). Therefore, for 19531968 , the correlation between Yichang and Datong was low $\left(R^{2}=0.47\right)$. In contrast, after the mid-1980s, the Hanjiang had almost stopped supplying sediment to the mainstream (10 Mt/yr in 1986-2002 vs. $122 \mathrm{Mt} / \mathrm{yr}$ in 1953-1968). In the same period of 1986-2002, the sediment depleted in Dongting Lake also decreased sharply to $47 \mathrm{Mt} / \mathrm{yr}$, or $11 \%$ of that at Yichang (Xu et al., 2007). The correlation between Yichang and Datong in 1986-2002, therefore, became more significant $\left(\mathrm{R}^{2}=0.89\right)$. Thus, the correlation in $1986-2002$ may well indicate the sediment transport process in the mid-lower Changjiang just before the TGD.

Based on the regression equation of 1986-2002 (Fig. 5b) and the estimated sediment load at Yichang in 2003-2008 


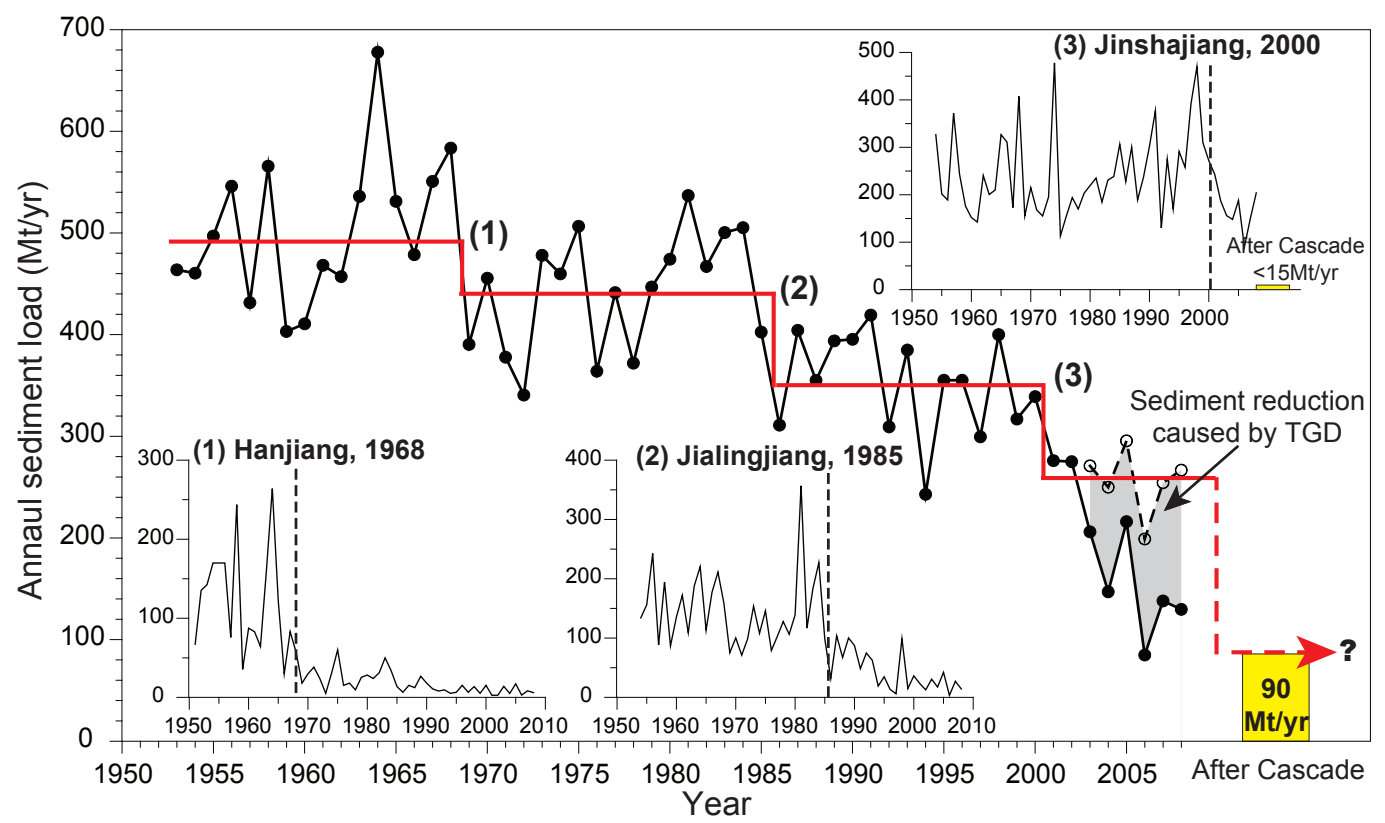

Fig. 6. Time series of the Changjiang sediment flux to the sea from 1953 to 2008 . The black circle is the measured sediment load at Datong, and the open circle represents the estimated sediment load at Datong in 2003-2008 in the case of no-TGD. Three phases of sediment reductions are displayed with the red line. The averaged value for 2001-2008 was calculated in the case of no-TGD. The first and second phases are consistent with Yang et al. (2006b). However, the Changjiang sediment flux had entered the third downward step in 2001 ahead of the TGD operations, corresponding to the sediment reduction in the Jinshajiang since the late 1990s. After the cascade reservoir on the lower Jinshajiang put into full operation, the changjiang sediment flux possibly further decrease to below $90 \mathrm{Mt} / \mathrm{yr}$. The grey region is the sediment reduction caused by TGD (102 Mt/yr in 2003-2008). See text for more detail.

(228 Mt/yr), mean annual sediment load at Datong had decreased by $91 \mathrm{Mt} / \mathrm{yr}$, from $352 \mathrm{Mt} / \mathrm{yr}$ in $1986-2000$ to $261 \mathrm{Mt} / \mathrm{yr}$ in 2001-2008 (non-TGD). This strongly implies that the third downward step in the Changjiang sediment flux happened even earlier, before the TGD. This can be mainly ascribed to increased reforestation and the construction of large hydraulic projects within the lower Jinshajiang basin since the late 1990s (Xu et al., 2006; Xiong et al., 2009). These human activities caused the Jinshajiang sediment discharge to sharply decline from $280 \mathrm{Mt} / \mathrm{yr}$ in $1986-2000$ to $171 \mathrm{Mt} / \mathrm{yr}$ in $2001-2008$ (Fig. 6). Sediment reduction induced by the TGD at Datong was estimated at $102 \mathrm{Mt} / \mathrm{yr}$ in 2003-2008 (gray region in Fig. 6), which is larger than the values given by Yang et al. (2007b).

\subsection{Future trend of the Changjiang sediment flux to the sea}

The correlation between sediment load at Yichang and Datong before the TGD was implemented has been applied to forecast the Changjiang sediment flux after the TGD in the previous studies (e.g., Yang et al., 2002, 2003, 2005, 2006b). However, it should be noted that the correlation between Yichang and Datong after the TGD has been fundamentally changed (Fig. 5b). This is mainly as a result of the changed sediment dynamics downstream of the TGD, such as the changed sediment transport regimes, the transition from deposition to erosion and the shrinking Doting Lake (Xu et al., 2007, Yang et al., 2007a; Hu et al., 2009; Xu and Milliman, 2009). Thus, the correlation before the TGD may not represent the sediment transport process in the mid-lower Changjiang over the post-TGD period.

In spite of some uncertainties in the correlation between Yichang and Datong after TGD, owing to their relatively short period (2003-2008), it was applied to provide an insight into the future trend of the Changjiang sediment flux over the post-TGD period. According to the regression equation for the post-TGD period (Fig. 5b), the sediment load at Datong will decrease to $100 \mathrm{Mt} / \mathrm{yr}$ when sediment load at Yichang is further decrease to $19 \mathrm{Mt} / \mathrm{yr}$ in the next decade. Moreover, several other factors will cause further reduction in the Changjiang sediment flux to the sea in the near future, as detailed below.

First of all, the South to North Water Diversion Project (SNWDP) will be put into full operation in the 2030s. From then on it will divert about $5 \%$, or $45 \mathrm{~km}^{3}$, of the Changjiang annual water discharge through three passages to dry northern China, leading to $3 \%-5 \%$ of river sediment loss (Yang et al., 2002). Secondly, the Water and Soil Conservation Project (WSCP) has been implemented in the Changjiang basin since 1988. By 2008, the total area under control was 
estimated at over $90 \times 10^{3} \mathrm{~km}^{2}$, with an increasing rate of $5000 \mathrm{~km}^{2} / \mathrm{yr}$. The WSCP has partly accounted for the sediment reduction of the Jialingjiang in the 1990s and the Jinshajiang in the 2000s (Xu et al., 2006; Yang et al., 2006b). Around $15 \%$ of the total sediment reduction at Datong, from $504 \mathrm{Mt} / \mathrm{yr}$ in $1956-1965$ to $320 \mathrm{Mt} / \mathrm{yr}$ in $1993-2002$, was attributed to the effects of the WSCP (Dai et al., 2008). The Chinese government has approved a plan to protect and recover an additional area of $75 \times 10^{3} \mathrm{~km}^{2}$ within the Changjiang basin in the next decade. Therefore, the WSCP would, to a great extent, further decrease the Changjiang sediment flux to the sea in the next decade.

Last, in response to the TGD trapping, the downstream reaches of the TGD have suffered from severe erosion (Dai et al., 2006; Yang et al., 2006b, 2007a, b; Xu et al., 2006; Chen et al., 2008; Xu and Milliman, 2009). About $70 \mathrm{Mt} / \mathrm{yr}$ of sediment was eroded from the channel between Yichang and Datong in 2003-2008 (data in 2003-2006 were after $\mathrm{Xu}$ and Milliman (2009)). These channel erosion sediments accounted for $45 \%$ of the Changjiang sediment flux to the sea in 2003-2008. The erosion magnitude decreased along the downstream direction in 2003-2008, when the sediment erosion rate was $0.1 \mathrm{Mt} / \mathrm{km} / \mathrm{yr}$ for the TGD site-Yichang, $0.07 \mathrm{Mt} / \mathrm{km} / \mathrm{yr}$ for Yichang-Hankou, and $0.05 \mathrm{Mt} / \mathrm{km} / \mathrm{yr}$ for Hankou-Datong. The erosion capacity will decrease with an increase in water depth, and the maximum erosion depth will extend downstream from the TGD site to Datong within 60 years (Lu, 2002; Yang et al., 2007a, b). Thus, sediment availability will be a limiting factor influencing sediment recovery downstream of the TGD on a long-term time scale (Yang et al., 2007b; Chen et al., 2008).

Taking the above-mentioned factors into account, the Changjiang sediment flux to the sea is conservatively expected to be less than $90 \mathrm{Mt} / \mathrm{yr}$ in the coming decades, when the cascade reservoir upstream of the TGD is put into full operation (Fig. 6). This value is not only much lower than most of the values predicted by previous studies (e.g., Yang et al., 2002, 2003, 2006b), but also lower than the minimum values given by Yang et al. (2007a) and Chen et al. (2008). Furthermore, for a longer time scale, when sediment entrainment downstream of the TGD is exhausted, the Changjiang sediment flux to the sea will possibly decrease further.

\section{Conclusions}

Our study shows that the TGD annually trapped about $172 \mathrm{Mt}$ of sediment coming from the upper Changjiang in 20032008, which is higher than the values published by the CWRC and those estimated by previous studies. These differences are mainly a result of the underestimation or neglect of siltation in the backwater region of the TGD. The sediment budgets show that $88 \%$ of the total sediment trapped by the TGD is deposited in the lower section, from the TGD site to Cuntan. The remaining $12 \%$ is deposited in the upstream of Cuntan as a result of the effect of the extended backwater area of the TGD.

Owing to the sediment reduction of the Jinshajiang since 2000, the sediment discharge from the Changjiang to the sea entered a third downward step in 2001, ahead of the TGD operation. The proposed cascade reservoir on the lower Jinshajiang may potentially trap $91 \%$ of the sediment coming from the Jinshajiang basin when it is put into full operation in the next decade. Consequently, the sediment discharge from the Changjiang to the sea will probably decrease to less than $90 \mathrm{Mt} / \mathrm{yr}$ in the coming decades, or only $18 \%$ of that in the 1950s. In response to the lower sediment supply, the Changjiang subaqueous delta will be eroded extensively, and a series of profound geological, morphological, ecologi$\mathrm{cal}$, and biogeochemical responses will appear in the estuary, delta, and coastal sea.

Acknowledgements. We are grateful to the Changjiang Water Resources Commission (CWRC) for the access to the valuable data sets. He Minxue (Kevin) and two anonymous reviewers are highly appreciated for their constructive comments, suggestions, and critical reviews. Thanks also give to Editor Matjaz Mikos for his kindly comments on an earlier draft. This work was financially supported by National Natural Science Foundation of China (NSFC) (Grant No. 40676035).

Edited by: M. Mikos

\section{References}

Bettess, R.: Sediment and backwater aspects of Sardar Sarovar Project, HR Wallingford, Report EX2761, 1993.

Brune, G. M.: Trap efficiency of reservoirs, Transactions of the American Geophysical Union, 34, 407-418, 1953.

Bulletin of Changjiang Sediment: Press of Ministry of Water Resources of the People's Republic of China, available at: http: //www.cjh.com.cn/, Beijing, 2000 (in Chinese).

Bulletin of Changjiang Sediment: Press of Ministry of Water Resources of the People's Republic of China, available at: http: //www.cjh.com.cn/, Beijing, 2001 (in Chinese).

Bulletin of Changjiang Sediment: Press of Ministry of Water Resources of the People's Republic of China, available at: http: //www.cjh.com.cn/, Beijing, 2002 (in Chinese).

Bulletin of Changjiang Sediment: Press of Ministry of Water Resources of the People's Republic of China, available at: http: //www.cjh.com.cn/, Beijing, 2003 (in Chinese).

Bulletin of Changjiang Sediment: Press of Ministry of Water Resources of the People's Republic of China, available at: http: //www.cjh.com.cn/, Beijing, 2004 (in Chinese).

Bulletin of Changjiang Sediment: Press of Ministry of Water Resources of the People's Republic of China, available at: http: //www.cjh.com.cn/, Beijing, 2005 (in Chinese).

Bulletin of Changjiang Sediment: Press of Ministry of Water Resources of the People's Republic of China, available at: http: //www.cjh.com.cn/, Beijing, 2006 (in Chinese). 
Bulletin of Changjiang Sediment: Press of Ministry of Water Resources of the People's Republic of China, available at: http: //www.cjh.com.cn/, Beijing, 2007 (in Chinese).

Bulletin of Changjiang Sediment: Press of Ministry of Water Resources of the People's Republic of China, available at: http: //www.cjh.com.cn/, Beijing, 2008 (in Chinese).

Chen, J. S., Wang, F. Y., Xia, X. H., and Zhang, L. T.: Major element chemistry of the Changjiang (Yangtze River), Chem. Geol., 187(3-4), 231-255, 2002.

Chen, X. Q., Zhang, E. F., Mu, H. Q., and Zong, Y.: A preliminary analysis of human impacts on sediment discharges from the Yangtze, China, into the sea, J. Coastal Res., 21(3), 515-521, 2005.

Chen, X. Q., Yan, Y., Fu, R. S., Dou, X., and Zhang, E. F.: Sediment transport from the Yangtze River, China, into the sea over the Post-Three Gorge Dam Period: A discussion, Quatern. Int., 186, 55-64, 2008.

Chen, Z. Y., Li, J. F., Shen, H. T., and Wang, Z. H.: Yangtze River of China: historical analysis of discharge variability and sediment flux, Geomorphology, 41, 77-91, 2001.

Chu, Z. X. and Zhai, S. K.: Yangtze River Sediment: In Response to Three Gorges Reservoir (TGR) Water Impoundment in June 2003, J. Coastal Res., 24, 30-39, 2008.

Dai, Shi-bao, Yang, Shi-lun, Zhu, Jun, Gao, Ang, and Li, Peng: The role of Lake Dongting in regulating the sediment budget of the Yangtze River, Hydrol. Earth Syst. Sci., 9, 692-698, 2005, http://www.hydrol-earth-syst-sci.net/9/692/2005/.

Dai, S. B., Yang, S. L., and Li, P.: Regulation of the main river channel to the sediment discharge of Yangtze catchment, Acta Geographica Sinica, 61, 461-470, 2006 (in Chinese with English abstract).

Dai, S. B., Lu, X. X., Yang, S. L., and Cai, A. M.: A preliminary estimate of human and natural contributions to the decline in sediment flux from the Yangtze River to the East China Sea, Quatern. Int., 186(1), 43-54, 2008.

El-Manadely, M. S., Abdel-Bary, R. M., El-Sammany, M. S., and Ahmed, T. A.: Characteristics of the delta formation resulting from sediment deposition in Lake Nasser, Egypt: Approach to tracing lake delta formation, Lakes \& Reservoirs: Research and Management, 7, 81-86, 2002.

Fu, R. S., Qi, M. L., Fang, H. W., and Chen, X. Q.: Influence of hydro-engineering projects in the upper Yangtze River on the changes of water and sediment output from Yichang Station, Journal of Hydroelectric Engineering, 24, 103-110, 2006 (in Chinese with English abstract).

Goodwin, P., Falte, M., and Betts, A. D. K.: Managing for unforeseen consequences of large dam operations, Working Paper of the World Commission on Dams, Vlaeberg, Cape Town, South Africa, 4-5, 2001.

Huang, Y. and Huang, Y. L.: Assessment on impact of Xiluodu on sediment deposition in Three Gorges Reservoir, China Three Gorges Construction, 9, 16-19, 2002 (in Chinese with English abstract).

Hu, Y. F., Wu, W. M., and Chen, Z. H.: Reservoir sediment computation of Xiangjiaba hydropower plant, Yangtze River, 34, 36-38, 2003 (in Chinese with English abstract).

Hu, B. Q., Wang, H. J., Yang, Z. S., and Sun, X. X.: Temporal and spatial variations of sediment rating curves in the Changjiang (Yangtze River) basin and their implications, Quatern. Int., doi:10.1016/j.quaint.2009.08.018, in press, 2009.

Goodwin, P., Falte, M., and Betts, A. D. K.: Managing for unforeseen consequences of large dam operations, Working Paper of the World Commission on Dams, Vlaeberg, Cape Town, South Africa, 4-5, 2001.

Kondolf, G. M.: Hungry Water: Effects of Dams and Gravel Mining on River Channels, Environ. Manage., 21, 533-551, 1997.

Kummu, M. and Varis, O.: Sediment-related impacts due to upstream reservoir trapping, the Lower Mekong River, Geomorphology, 85, 275-293, 2007.

Liu, F.: Introduction of the planed hydroelectric engineering on the lower Jinshajiang, Construction of Water Resources \& Hydroelectric Engineering, 3, 153-155, 2007 (in Chinese).

Lu, J. Y.: Impact of downstream erosion of the Three Gorges Dam on protective bank structures, Yangtze River, 33, 23-25, 2002 (in Chinese with English abstract).

Milliman, J. D. and Meade, R. H.: World-Wide Delivery of River Sediment to the Oceans, J. Geol., 91, 1-21, 1983.

Milliman, J. D. and Syvitski, J. P. M.: Geomorphic/tectonic control of sediment transport to the ocean: the importance of small mountainous rivers, J. Geol., 100, 525-544, 1992.

Milliman, J. D.: Blessed dams or damned dams?, Nature, 386, 325327, 1997.

Morris, G. L. and Fan, J.: Reservoir Sedimentation Handbook: Design and Management of Dams, Reservoirs, and Watersheds for Sustainable Use, McGraw-Hill Professional, 1998.

Nilsson, C., Reidy, C. A., Dynesius, M., and Revenga, C.: Fragmentation and Flow Regulation of the World's Large River Systems, Science, 308, 405-408, 2005.

Shen, G. Z. and Xie, Z. Q.: Three Gorges Project: Chance and Challenge, Science, 304, 681, doi:10.1126/science.304.5671.681b, 2004.

Snyder, N. P., Rubin, D. M., Alpers, C. N., Childs, J. R., Curtis, J. A., Flint, L. E., and Wright, S. A.: Estimating accumulation rates and physical properties of sediment behind a dam: Englebright Lake, Yuba River, northern California, Water Resour. Res., 40, W11301, doi:10.1029/2004WR003279, 2004.

Syvitski, J. P. M., Vorosmarty, C. J., Kettner, A. J., and Green, P.: Impact of Humans on the Flux of Terrestrial Sediment to the Global Coastal Ocean, Science, 308, 376-380, 2005.

Tang, J. and He, X. P.: Impoundment of the Xiluodu Reservoir and its impact on the lower reaches, Design of Hydroelectric Power Station, 19, 60-63, 2003 (in Chinese with English abstract).

UNDES: United Nations Department of Economic and Social Affairs, New York, 2001.

Vörösmarty, C. J., Meybeck, M., Fekete, B., and Sharma, K.: The potential impact of neocastorization on sediment transport by the global network of rivers, in: Human impact on erosion and sedimentation, edited by: Walling, D. E. and Probst, J. L., IAHS Press, Wallingford, UK, 261-272, 1997.

Vörösmarty, C. J., Meybeck, M., Fekete, B., Sharma, K., Green, P., and Syvitski, J. P. M.: Anthropogenic sediment retention: major global impact from registered river impoundments, Global Planet. Change, 39, 169-190, 2003.

Walling, D. E. and Fang, D.: Recent trends in the suspended sediment loads of the world's rivers, Global Planet. Change, 39, 111126, 2003. 
Walling, D. E.: Human impact on land-ocean sediment transfer by the world's rivers, Geomorphology, 79, 192-216, 2006.

Wang, H. J., Yang, Z. S., Wang, Y., Saito, Y., and Liu, J. P.: Reconstruction of sediment flux from the Changjiang (Yangtze River) to the sea since the 1860s, J. Hydrol., 349, 31-332, 2008.

Wang, J., Zhang, O. Y., and Xiong, M.: The impact of initial water impoundment on sediment transport of Three Gorges Reservoir, Journal of Hydroelectric Engineering, 26, 98-108, 2007a (in Chinese with English abstract).

Wang, Z. Y., Wu, B. S., and Wang, G. Q.: Fluvial processes and morphological response in the Yellow and Weihe Rivers to closure and operation of Sanmenxia Dam, Geomorphology, 91, 65$79,2007 \mathrm{~b}$.

WCD: Dams and Development: A New Framework for Decisionmaking, Earthscan, London and Sterling, VA, 2000.

Xie, P., Wu, J. G., Huang, J. H., and Han, X. G.: Three-Gorges Dam: Risk to Ancient Fish, Science, 302, 1149-1151, 2003.

Xiong, M., Xu, Q. X., and Yuan, J.: Analysis of multi-factors affecting sediment load in the Three Gorges Reservoir, Quatern. Int., 208 (1-2), 76-84, 2009.

Xu, K. H., Milliman, J. D., Yang, Z. S., and Wang, H. J.: Yangtze Sediment Decline Partly From Three Gorges Dam, Eos Trans. AGU, 87, 185-190, 2006.

Xu, K. H., Milliman, J. D., Yang, Z. S., and Xu, H.: Climatic and Anthropogenic Impacts on Water and Sediment Discharges from the Yangtze River (Changjiang), 1950-2005, in: Large Rivers, edited by: Avijit, G., 609-626, 2007.

$\mathrm{Xu}, \mathrm{K} . \mathrm{H}$. and Milliman, J. D.: Seasonal variations of sediment discharge from the Yangtze River before and after impoundment of the Three Gorges Dam, Geomorphology, 104, 276-283, 2009.

Yang, S. L., Zhao, Q. Y., and Belkin, I. M.: Temporal variation in the sediment load of the Yangtze river and the influences of human activities, J. Hydrol., 263, 56-71, 2002.
Yang, S. L., Belkin, I. M., Belkina, A. I., Zhao, Q. Y., Zhu, J., and Ding, P. X.: Delta response to decline in sediment supply from the Yangtze River: evidence of the recent four decades and expectations for the next half-century, Estuar. Coast Shelf Sci., 57, 689-699, 2003.

Yang, S. L., Zhang, J., Zhu, J., Smith, J. P., Dai, S. B., Gao, A., and Li, P.: Impact of dams on Yangtze River sediment supply to the sea and delta intertidal wetland response, J. Geophys. Res., 110, F03006, doi:10.1029/2004jf000271, 2005.

Yang, S. L., Li, M., Dai, S. B., Liu, Z., Zhang, J., and Ding, P. X.: Drastic decrease in sediment supply from the Yangtze River and its challenge to coastal wetland management, Geophys. Res. Lett., 33, L06408, doi:10.1029/2005g1025507, 2006a.

Yang, S. L., Zhang, J., Dai, S. B., Li, M., and Xu, X. J.: Effect of deposition and erosion within the main river channel and large lakes on sediment delivery to the estuary of the Yangtze River, J. Geophys. Res., 112, F02005, doi:10.1029/2006jf000484, 2007a.

Yang, S. L., Zhang, J., and Xu, X. J.: Influence of the Three Gorges Dam on downstream delivery of sediment and its environmental implications, Yangtze River, Geophys. Res. Lett., 34, L10401, doi:10.1029/2007g1029472, 2007b.

Yang, Z. S., Wang, H. J., Saito, Y., Milliman, J. D., Xu, K. H., Qiao, S. Q., and Shi, G. Y.: Dam impacts on the Changjiang (Yangtze) River sediment discharge to the sea: The past 55 years and after the Three Gorges Dam, Water Resour. Res., 42, W04407, doi:10.1029/2005wr003970, 2006b.

Zhao, C. H., Zhu, Z. H., and Zhou, D. Z.: Worldwide Rivers and Dams, China Water Conservancy and Hydroelectr. Press, Beijing, 1059 pp., 2000 (in Chinese).

Zhang, Q., Xu, C. Y., Singh, V. P., and Yang, T.: Multiscale variability of sediment load and streamflow of the lower Yangtze River basin: Possible causes and implications, J. Hydrol., 368(1-4), 96-104, 2009. 